\title{
Staphylococcus aureus in Domestic Animals
}

\author{
S. M. MORRISON, Ph.D., J. F. FAIR, B.S., and K. K. KENNEDY, M.S.
}

$\mathbf{R}$ EALIZATION of the significance of staphylococci as pathogenic organisms for humans has increased greatly in the past few years. This has been largely due to the emergence of antibiotic-resistant strains; hospitals have experienced, and are continuing to experience, increased numbers of suppurative staphylococcal infections in nurseries, maternity wards, and surgical units. In numerous cases the incidence of these infections has reached epidemic proportions (1). The severity of hospital infections, as well as the apparent ease of dissemination of antibiotic-resistant Staphylococous aureus within hospitals has led to studies relating to the spread of these organisms to the community at large. Discharged hospital patients and hospital employees, such as nurses, have been regarded as the primary source of dissemination of infection to the community (2). This conclusion has been reached as a result of studies dealing with the incidence of staphylococcal infections in families which have had some member hospitalized (1). Studies have also been made to determine if members of similarly situated families may become carriers of so-called hospital types of staphylococci. Most of these studies indicate that discharged hospital patients may transmit co-

The authors are with the Colorado State University, Fort Collins. Dr. Morrison is professor of microbiology, department of pathology and bacteriology; Mr. Fair and Mr. Kennedy are graduate students in microbiology. The study was carried out in coop. eration with the Colorado State Department of Public Health, with the support of the Communicable Disease Center, Public Health Service. Supplemental financial aid was provided by the National Science Foundation Undergraduate Research Participation Program. agulase-positive, antibiotic-resistant Staphylococcus having phage types identical to those found in hospital outbreaks and epidemics. Although this seems to be the most feasible route of transmission to the community at large, there exists no evidence which limits transmission of these organisms to this route.

In 1947 Foggie (3) published a report on the carriage of coagulase-positive Staphylococcus by a herd of lambs in Scotland. He found that coagulase-positive organisms could be isolated quite readily from the mouth, nose, and vagina of the animals. Gustafson and Svehag in 1956 isolated 259 coagulase-positive organisms from a group of 292 dogs suffering from otitis externa (4). The antibiotic resistance of these organisms to penicillin, streptomycin, and terramycin was less than 5 percent. However, with 33 nonpathogenic strains the percentage of resistance was considerably greater; 36 percent in the case of terramycin. Also in 1956, Rountree, Freeman, and Johnston (5) published a report of their findings in a study of nasal carriage of Staphylococcus by domestic and laboratory animals. They found that 11.5 percent of the dogs studied carried coagulase-positive organisms, and that among the typable cultures were to be found the socalled human types. In 1959, Mann (6) surveyed 100 dogs and 100 cats and found that 23 percent of the dogs and 7 percent of the cats harbored coagulase-positive staphylococci. Mann was successful in typing only two of the coagulase-positive cultures with "human phages." Pagano and co-workers (7) reported that they were able to isolate coagulasepositive staphylococci from 45 of 137 animals being studied in a veterinary clinic, the greatest percentage of the isolations being from dogs. Ten percent of the isolations were of 
phage type $80 / 81$, the Staphylococcus strain which has been termed the "hospital type."

Rajulu and associates (8) have reported a high incidence of staphylococci in canines visiting the Kansas State University Veterinary Hospital. Of 32 dogs that were examined, 88 percent were found to carry coagulase-positive strains.

The investigation reported here was initiated to study domestic animals as another possible focal source of transmission of potentially pathogenic antibiotic-resistant, coagulase-positive $S$. aureus. It is a portion of a broader epidemiologic study currently in progress at the Colorado State University Veterinary Clinic.

\section{Materials and Methods}

Animals used in this survey (canine, feline, bovine, and equine) were from the wards of the veterinary clinic. Samples were obtained with dry swabs from the anterior nares of the test animals, and by swabbing the dorsal and lateral surfaces of the thoracic region with sterile cotton swabs moistened in sterile physiological saline.

Primary isolation of nasal samples was made on blood agar (tryptose agar base plus citrated human whole blood) followed by subculture of growth on mannitol salt agar (Difco) and then transfer to nutrient agar slants, from which gram stains were made. Once the morphological purity of the cultures was established, the slants were stored at refrigerator temperature until further use in coagulase and antibiotic sensitivity testing.

Primary isolation of skin samples was made on mannitol salt agar. This variation in the isolation procedure described above was found desirable in order to reduce the amount of contamination due to spreading Bacillus species, a problem which was not encountered with nasal samples. Subcultures of skin samples were then made on blood agar, and the above described protocol was followed. All cultures were incubated aerobically for 24 hours at $37^{\circ} \mathrm{C}$.

Coagulase testing was made by the tube

Table 1. Staphylococci isolated from animals in Colorado State University Veterinary Clinic, Fort Collins, Colo.

\begin{tabular}{|c|c|c|c|c|c|c|c|c|c|c|c|c|c|}
\hline & \multirow{3}{*}{$\begin{array}{l}\text { Percent- } \\
\text { ages } \\
\text { based } \\
\text { on- }\end{array}$} & \multicolumn{4}{|c|}{ Canine } & \multicolumn{4}{|c|}{ Other 1} & \multicolumn{4}{|c|}{ Total } \\
\hline & & \multicolumn{2}{|c|}{ Nares } & \multicolumn{2}{|c|}{ Skin } & \multicolumn{2}{|c|}{ Nares } & \multicolumn{2}{|c|}{ Skin } & \multicolumn{2}{|c|}{ Nares } & \multicolumn{2}{|c|}{ Skin } \\
\hline & & $\underset{\text { ber }}{\text { Num- }}$ & $\begin{array}{l}\text { Per- } \\
\text { cent }\end{array}$ & $\begin{array}{c}\text { Num- } \\
\text { ber }\end{array}$ & $\begin{array}{l}\text { Per- } \\
\text { cent }\end{array}$ & $\underset{\text { ber }}{\text { Num- }}$ & $\begin{array}{l}\text { Per- } \\
\text { cent }\end{array}$ & $\begin{array}{c}\text { Num- } \\
\text { ber }\end{array}$ & $\begin{array}{l}\text { Per- } \\
\text { cent }\end{array}$ & $\begin{array}{c}\text { Num- } \\
\text { ber }\end{array}$ & $\begin{array}{l}\text { Per- } \\
\text { cent }\end{array}$ & $\begin{array}{c}\text { Num- } \\
\text { ber }\end{array}$ & $\begin{array}{l}\text { Per- } \\
\text { cent }\end{array}$ \\
\hline a. Samples taken.- & $\ldots$ & 153 & 100.0 & 58 & 100.0 & 92 & 100.0 & 59 & 100.0 & 245 & 100.0 & 117 & 100.0 \\
\hline b. Isolations. & $\mathrm{b} / \mathrm{a}$ & 140 & 91.5 & 39 & 67.2 & 79 & 85.9 & 50 & 84.7 & 219 & 89.4 & 89 & 76 \\
\hline c. Coagulase-positive & $\mathrm{c} / \mathrm{b}$ & 95 & 67.8 & 23 & 59.0 & 28 & 35.4 & 9 & 18.0 & 123 & 56. 1 & 32 & 36. 0 \\
\hline $\begin{array}{l}\text { d. Coagulase-negative - } \\
\text { e. Coagulase-positive, }\end{array}$ & $\mathrm{d} / \mathrm{b}$ & 45 & |32.2 & 16 & 41.0 & 51 & 64.6 & 41 & 82.0 & 96 & 43. 9 & 57 & 64. 0 \\
\hline beta hemolytic & $\mathrm{e} / \mathrm{c}$ & 53 & 55. 8 & 10 & 43.5 & 9 & 32.1 & 2 & 22.2 & 62 & 50.4 & 12 & 37.5 \\
\hline $\begin{array}{l}\text { f. Coagulase-positive, } \\
\text { nonhemolytic }\end{array}$ & $\mathrm{f} / \mathrm{c}$ & 42 & 44. 2 & 13 & 56.5 & 19 & 67.9 & 7 & 77.8 & 61 & 49. 6 & 20 & 62.5 \\
\hline $\begin{array}{l}\text { g. Coagulase-negative, } \\
\text { beta hemolytic }\end{array}$ & $\mathrm{g} / \mathrm{d}$ & 29 & 64.5 & 8 & 50.0 & 7 & 13.7 & 9 & 22.0 & 36 & 37.5 & 17 & 29. 8 \\
\hline h. Coagulase-negative & & & & & & & & & & & & & \\
\hline $\begin{array}{l}\text { nonhemolytic } \\
\text { i. Coagulase-positive, }\end{array}$ & $\mathrm{h} / \mathrm{d}$ & 16 & 35.5 & 8 & $\mid 50.0$ & 44 & 86.3 & 32 & 78. 0 & 60 & 62.5 & 40 & 70. 2 \\
\hline $\begin{array}{l}\text { mannitol-positive } \\
\text { j. Coagulase-positive }\end{array}$ & $\mathrm{i} / \mathrm{c}$ & 38 & 40.0 & 14 & 60.9 & 26 & 92.9 & 7 & 77.8 & 64 & 52.0 & 21 & 62. 5 \\
\hline mannitol-negative & $\mathrm{j} / \mathrm{c}$ & 57 & 60.0 & 9 & 39.1 & 2 & 7. 1 & 2 & 22.2 & 59 & 48. 0 & 11 & 37.5 \\
\hline $\begin{array}{l}\text { K. Coagulase-negative, } \\
\text { mannitol-positive }\end{array}$ & $\mathrm{k} / \mathrm{d}$ & 13 & 28. 9 & 7 & 43.8 & 41 & 80.4 & 31 & 75.6 & 54 & 56.3 & 38 & 66. 7 \\
\hline $\begin{array}{l}\text { 1. Coagulase-negative, } \\
\text { mannitol-negative }\end{array}$ & $1 / d$ & 32 & 71.1 & 9 & 56.2 & 10 & 19.6 & 10 & 24. 4 & 42 & 43. 7 & 19 & 33. 3 \\
\hline
\end{tabular}

\footnotetext{
${ }^{1}$ Feline, bovine, and equine.
} 
Table 2. Antibiotic resistance of coagulase-positive Staphylococcus cultures from animals at Colorado State University Veterinary Clinic, Fort Collins, Colo.

\begin{tabular}{|c|c|c|c|c|c|c|c|c|c|c|}
\hline \multirow{3}{*}{ Antibiotic $^{1}$ and concentration used ${ }^{2}$} & \multicolumn{4}{|c|}{ Canine } & \multicolumn{2}{|c|}{ Other $^{3}$} & \multicolumn{4}{|c|}{ Total } \\
\hline & \multicolumn{2}{|c|}{ Nares } & \multicolumn{2}{|c|}{ Skin } & \multirow{2}{*}{$\frac{\text { Nares }}{\substack{\text { Num- } \\
\text { ber }}}$} & \multirow{2}{*}{$\begin{array}{c}\text { Skin } \\
\substack{\text { Num- } \\
\text { ber }}\end{array}$} & \multicolumn{2}{|c|}{ Nares } & \multicolumn{2}{|c|}{ Skin } \\
\hline & $\underset{\text { ber }}{\text { Num- }}$ & $\begin{array}{l}\text { Per- } \\
\text { cent }\end{array}$ & $\underset{\text { ber }}{\text { Num- }}$ & $\begin{array}{l}\text { Per- } \\
\text { cent }\end{array}$ & & & $\underset{\text { ber }}{\text { Num- }}$ & $\begin{array}{l}\text { Per- } \\
\text { cent }\end{array}$ & $\underset{\text { ber }}{\text { Num- }}$ & $\begin{array}{l}\text { Per- } \\
\text { cent }\end{array}$ \\
\hline Coagulase-positive cultures $\ldots$ & 95 & 100.0 & 23 & 100.0 & 28 & 9 & 123 & 100.0 & 32 & 100. 0 \\
\hline $\begin{array}{l}\text { Penicillin (2 units) } \\
\text { Dihydrostreptomycin }(2 \mu \mathrm{g} .) \\
\text { Chloromycetin }(5 \mu \mathrm{g} .) \\
\text { Erythromycin }(2 \mu \mathrm{g} .) \\
\text { Novobiocin }(5, \mu \mathrm{g} .) \\
\text { Terramycin }(5 \mu \mathrm{g} .)\end{array}$ & $\begin{array}{r}69 \\
56 \\
5 \\
4 \\
3 \\
45\end{array}$ & $\begin{array}{r}\text { 72. } 6 \\
\text { 58. } 9 \\
\text { 5. } 3 \\
\text { 4. } 2 \\
\text { 3. } 2 \\
\text { 47. } 4\end{array}$ & $\begin{array}{r}19 \\
17 \\
0 \\
0 \\
0 \\
16\end{array}$ & $\begin{array}{r}82.6 \\
73.9 \\
.0 \\
.0 \\
.0 \\
69.6\end{array}$ & $\begin{array}{r}12 \\
14 \\
4 \\
9 \\
8 \\
13\end{array}$ & $\begin{array}{l}2 \\
3 \\
1 \\
1 \\
0 \\
2\end{array}$ & $\begin{array}{r}81 \\
70 \\
9 \\
13 \\
11 \\
58\end{array}$ & $\begin{array}{r}65.8 \\
56.9 \\
7.3 \\
10.6 \\
8.9 \\
47.1\end{array}$ & $\begin{array}{r}21 \\
20 \\
1 \\
1 \\
0 \\
18\end{array}$ & $\begin{array}{r}65.6 \\
62.5 \\
3.1 \\
3.1 \\
.0 \\
56.2\end{array}$ \\
\hline
\end{tabular}

13 other antibiotics (neomycin, $5 \mu \mathrm{g}$.; carbomycin, $2 \mu \mathrm{g}$.; and ristocetin, $5 \mu \mathrm{g}$.) were used in the survey but are not included in this table; only 1 culture was resistant to each of these antibiotics.

2 BBL Sensi-disc.

3 Numbers too small to give significant percentages.

method (9) with freshly drawn, citrated rabbit plasma, initially diluted $1: 4$ in sterile buffered physiological saline. One-half milliliter of the diluted plasma was added to $0.5 \mathrm{ml}$. of nutrient broth (final plasma dilution 1:8) which had been previously inoculated with the test organism. Known coagulase-positive and coagulasenegative staphylococci and plasma controls were included in each group of tests. All tubes were incubated at $37^{\circ} \mathrm{C}$. for 24 hours before final reading. No attempt was made to differentiate weak and strong coagulase producers; any visible degree of coagulation was recorded as a positive test.

Antibiotic sensitivity testing of the coagulasepositive cultures was on blood agar plates. Eight Baltimore Biological Laboratories (BBL) Sensi-discs (penicillin 5 units, dihydrostreptomycin $2 \mu \mathrm{g}$., chloromycetin $5 \mu \mathrm{g}$., erythromycin $2 \mu \mathrm{g}$., neomycin $5 \mu \mathrm{g}$., novobiocin $5 \mu \mathrm{g}$., terramycin $5 \mu \mathrm{g}$., carbomycin $2 \mu \mathrm{g}$.) were applied simultaneously to each plate using a BBL Sensi-disc applicator. A ninth disk (ristocetin $5 \mu$ g.) was applied manually. All disks were applied immediately after uniformly inoculating the agar surface with the test organism, and all plates were incubated aerobically at $37^{\circ} \mathrm{C}$. for 24 hours before reading. Since only one concentration of each antibiotic was used, reactions were recorded only as being sensitive or resistant, sensitivity being characterized by a well-defined clear zone of inhibition.

Phage typing was performed by the staff of the New Mexico State Public Health Laboratory at Albuquerque. A basic set of 22 phages was used at the critical test dilution (CTD), and cultures that were untypable at the CTD were rechecked with phages at 10 times the CTD before reporting them as untypable.

\section{Results}

Eighty-nine percent of all the animals sampled yielded cultures of staphylococci from the nose. Fifty-six percent of the total nasal isolants were coagulase-positive by the tube method (table 1). Fewer coagulase-positive isolants were obtained from the skin of the animals surveyed. Both the canine and feline species demonstrated high carrier rates of coagulasepositive Staphylococcus on the skin as well as in the nose; the bovine and equine samples yielded staphylococci in high proportion from the nose and skin; however, the majority of these isolants were coagulase-negative.

The ability to produce coagulase and the ability to produce hemolysis on blood agar were compared (table 1). The number of hemolysinpositive and the number of hemolysin-negative 
cultures among all the coagulase-positive organisms were similar. The cultures from the most thoroughly studied species, the canine, demonstrated this equal division as an individual group. The other species demonstrated a greater percentage of nonhemolytic, coagulasepositive nasal isolants. Likewise, coagulasepositive organisms isolated from samples obtained by swabbing the skin were nonhemolytic for all species in well over half the cases. Sixty-four percent of the coagulasenegative nasal isolants from the canine were able to produce beta hemolysis on human blood agar. The other coagulase-negative nasal isolants were in general nonhemolytic.

A comparison of coagulase reaction and the ability to ferment mannitol showed, in the coagulase-positive nasal cultures from all species, almost equal division between mannitol fermenters and nonfermenters.

Coagulase-positive nasal and skin Staphylococcus in the canine and feline species showed marked resistance to penicillin, dihydrostreptomycin, and terramycin at the concentrations used (table 2). Bovine and equine skin isolants showed less resistance to these antibiotics.

The majority of coagulase-positive animal cultures were insensitive to the action of human typing phages; skin isolants were remarkably refractive to their action, with only 2 of 32 being successfully typed (table 3). Four strains were obtained which were sensitive to phages 80 and 81 . No correlation could be established between the phage type of an organism and its resistance to a given set of antibiotics.

\section{Discussion}

On the basis of our survey, it is obvious that the incidence of staphylococci in some domestic animals is quite high. Coagulase-positive Staphylococcus was readily obtained from the anterior nares and the skin surfaces of the canine and feline subjects. The bovine and equine test animals appeared to be less important as carriers of these organisms. Our experimental results verify the information published by two other groups of workers $(\%, 8)$, within limits of variation perhaps attributable to difference in sample size.

Pathogenic staphylococci have long been characterized by the production of coagulase,
Table 3. Susceptibility of animal Staphylococcus isolants to human typing phages

\begin{tabular}{c|r|r}
\hline Phage & Nares & \multicolumn{2}{|c}{ Skin } \\
\hline Types & 21 & 2 \\
Miscellaneous & 2 \\
42D & 0 & 0 \\
80/81. & 4 & 0 \\
\hline Untypable & 102 & 30 \\
\hline
\end{tabular}

${ }^{1}$ Lytic group-I $(29,52,52 \mathrm{~A}, 78,80)$, II $(3 \mathrm{~A}, 3 \mathrm{~B}, 3 \mathrm{C}$, $55,71)$, III $(6,7,42 \mathrm{E}, 47,54,73,75,77)$, miscellaneous (81) ; multiple groups-II and III, III and miscellaneous.

fermentation of mannitol, and production of hemolysins. This characterization has come about as the result of observations on isolants from infections known to be caused by Staphylococcus. The relationships among these characteristics are unfortunately obscure, and the validity of hemolysin production and mannitol fermentation as indicators of potential pathogenicity has yet to be firmly established. At present, the production of coagulase is generally accepted as the best indicator of pathogenic potential. Our results did not demonstrate any degree of relationship between the production of coagulase by animal nasal and skin isolants and the ability to hemolyze human erythrocytes and ferment mannitol. In the equine and bovine, however, there did appear to be a tendency for coagulase-positive isolants to be nonhemolytic but mannitol-positive.

This survey has yielded results pertaining to a frequent occurrence of resistance in animal Staphylococcus isolants to three commonly used antibiotics (penicillin, dihydrostreptomycin, and terramycin). This pattern of resistance might suggest that a common source existed for the organisms and, moreover, that the organisms were closely related. However, phage typing has not confirmed this. One can only speculate that the clinic environment was responsible for the resistances noted.

Our isolation of four organisms susceptible to phages 80 and 81 indicates that animals may be colonized by the epidemic "hospital type" staphylococci. Pagano and co-workers ( 7$)$ have reached similar conclusions. Contrary to Smith (10) and Coles and Eisenstark (11) our animal isolants were not susceptible to phage $42 \mathrm{D}$. 
The significance of the role of animals in the dissemination of pathogenic staphylococci to their human contacts will depend on the study of epidemiologic data in populations having close and prolonged contact with animals, as compared with unexposed human populations. Furthermore, it must be ascertained whether the high incidence of staphylococci in animals is merely a passive condition brought about by its human environment, or whether the animal may serve as an active transmitting medium of pathogenic staphylococci to humans. A study of this nature is currently in progress at the Colorado State University.

\section{Summary and Conclusions}

Results of a study to determine the incidence of coagulase-positive staphylococci in domestic animals indicated a high incidence of coagulasepositive, antibiotic-resistant Staphylococcus in these animals, particularly in the canine and the feline. Coagulase production, hemolytic reactions, ability to ferment mannitol, antibiotic resistances, and phage types were determined.

We propose, on the basis of this survey, that domestic animals may possibly serve as a source of pathogenic staphylococci, since the incidence and types of staphylococci isolated from them are indicative of a potential reservoir of pathogenic organisms.

\section{REFERENCES}

(1) Wentworth, F. H., Miller, A., and Wentworth, B. B.: Observations relative to the nature and control of epidemic staphylococcal disease. In Selected materials on staphylococcal disease. PHS Pub. No. 627. Washington. D.C..
U.S. Government Printing Office, 1958, pp. 111-122.

(2) Wentworth, F. H., Miller, A., and Wentworth, B. B. : Community aspects of hospital-acquired staphylococcal disease. In Proceedings of the National Conference on Hospital-Acquired Staphylococeal Disease. Atlanta, Ga., U.S. Communicable Disease Center, 1958, pp. 105111.

(3) Foggie, A.: Studies on the source of the staphylococcal infection found in tick pyaemia of lambs. J. Comp. Path. \& Therap. 57 : 245-260 (1947).

(4) Gustafson, B. A., and Svehag, A.: Resistenspvövning av stafylokocker isolerade från hund [Antibiotic resistance of staphylococci isolated from dogs]. Nord. veterinärmed. 8: 493-496 (1956).

(5) Rountree, P. M., Freeman, B. M., and Johnston, K. G.: Nasal carriage of Staphylococcus aureus by various domestic and laboratory animals. J. Path. \& Bact. 72: 319-321 (1956).

(6) Mann, P. H.: Antibiotic sensitivity testing and bacteriophage typing of staphylococci found in the nostrils of dogs and cats. J. Am. Vet. M.A. 134 : $469-470$ (1959).

(7) Pagano, J. S., et al.: Isolation from animals of human strains of staphylococci during an epidemic in a veterinary school. Science 131 : $927-928$ (1960).

(8) Rajulu, P. S., Foltz, V. D., and Lord, T. H.: The canine as a reservoir of pathogenic staphylococci. Am. J. Pub. Health 50: 74-78, June 1960, pt. 2.

(9) Proceedings of the National Conference on Hospital-Acquired Staphylococcal Disease. Atlanta, Ga., U.S. Communicable Disease Center, 1958, Appendix A.

(10) Smith, H. W.: The typing of staphylococci of animal origin by the bacteriophage method. J. Comp. Path. \& Therap. 58: 179-188 (1948).

(11) Coles, E. H., and Eisenstark, A.: The use of human typing phages and adapted human typing phages in the typing of Staphylococcus aureus of animal origin. Am. J. Vet. Res. 20: 835-837 (1959). 